\title{
Effect of an In-Service Training Program about Alzheimer's Disease on Knowledge and Attitude of Formal Caregivers in Damanhour City
}

\author{
Enas Mohamed Ibrahim, Assistant Professor \\ Community Health Nursing, Faculty of Nursing, Damanhour University \\ Reem Bassiouny El-Lassy, Assistant Professor \\ Community Health Nursing, Faculty of Nursing, Damanhour University
}

\begin{abstract}
Alzheimer's disease is one of the most upsetting chronic illnesses, affecting millions of elderly individuals and families across the world. Providing proper care for people with Alzheimer's disease is difficult and requires specific skills, attitudes, and knowledge. Objective: Evaluate the effect of an in-service training program about Alzheimer's disease on knowledge and attitude of formal caregivers in Damanhour City. Setting: The study was conducted at the available governmental residential home in Damanhour City. Subjects: All available formal caregivers, who accepted to participate in the study and caring for elders residing in the previously mentioned setting were included. Their total number amounted to 45 caregivers. Tools: An interview schedule was used to collect the required data. Results: More than half of caregivers stated mass media as the main sources of their knowledge about Alzheimer disease. There was statistical significant relation between caregiver's knowledge level and attitude regarding Alzheimer disease at post in-service training program. Conclusion: Caregivers who have good and satisfactory level of knowledge regarding Alzheimer disease also have positive attitude at post implementation of in-service training program. Recommendations: Expand the role of social media for increasing community awareness about caring for patient with Alzheimer.
\end{abstract}

Keywords: Alzheimer's Disease; Formal Caregivers; In-Service Training Program; Attitude; Knowledge.

\section{Introduction}

Alzheimer's disease (AD) and related Disorders (ADRD) are major public health problems and the most common cause of dementia, which possibly contributes to $60-70 \%$ of identified cases ${ }^{(1,2)}$. There are an estimated 7.4 million people living with dementia worldwide and at least 3.7 million with Alzheimer's disease (AD) ${ }^{(3)}$. Dementia is an umbrella term that describes a variety of diseases and conditions that develop when nerve cells in the brain (called neurons) die or no longer function normally. It is one of the most distressing chronic disease, affecting millions of elderly individuals and it is the single greatest cause of disability in old age ${ }^{(4)}$. The number of Alzheimer's disease is projected to double by $2020^{(5,6)}$.

Alzheimer's disease is a form of dementia that cripples the cognitive and physical aspects of a person's life ${ }^{(5,7)}$. The disease process is characterized by progressive and irreversible cognitive deterioration that can occur in individuals 45 years of age and older. The progression rate varies between individuals ${ }^{(2,8)}$. A variety of genetic, environmental and other factors can cause this disease $\mathrm{e}^{(9)}$.

The earliest stage of the disease is characterized by memory loss, agitation, anxiety, personality changes and sleep problems. Patients may be observed having difficulty following conversations or movies, and getting lost in familiar environments. Personality changes often occur in the context of diminished social skills, and increasingly poor judgment and insight. As intellectual deterioration progresses, these patients may develop language deficits characterized by wordfinding problems, impaired reading and writing skills, and difficulty with simple 
calculations. Eventually, memory problems generally worsen, and patients experience difficulty performing even overlearned tasks such as cooking, sewing or driving. Late stage of $\mathrm{AD}$ is characterized by loss of control over physical functions. As well as problems with walking, bowel and bladder control, and disorientation. This can eventually result in total dependency on caregivers in the community, or on medical treatment in institutions or nursing homes $^{(2,7)}$.

Care is a multidimensional phenomenon, a cultural experience and interesting field in medical sciences, especially when it involves care for patients in nursing homes who have Alzheimer disease with cognitive deficits and behavioral disturbances ${ }^{(10)}$. Providing proper care for people with Alzheimer's disease is difficult and requires specific skills, attitudes, and knowledge ${ }^{(11)}$. The Alzheimer's Association had indicated that almost 15 million caregivers are providing care to those diagnosed with Alzheimer's disease and dementia $(2011)^{(6)}$.

Formal care refers to paid care services by a healthcare institution or individual for a person in need. They may be professionals, support workers, or volunteers. This service is available in most countries privately and publically although public formal care is significantly more limited than private options. It is widely recognized that formal care is often a last case resort which is only chosen by family members or friends who can no longer provide the necessary care to their loved one $^{(12)}$.

Caregivers of persons with Alzheimer's disease and related dementias usually confront a more challenging and unique set of problems than do caregivers of individuals with general disabilities. If caregivers didn't get adequate supports, they may experience increased strain as the disease progresses, increasing the likelihood of unnecessary institutionalization of their care recipients and increasing the cost to the public $^{(13)}$. Researchers report extensive mental illness among dementia carers. Poor morale, poor general mental health, perceived strain and depression have also been reported. Women caregivers experience greater mental and physical strain, burden of caregiving, and higher levels of psychological distress than men caregivers $^{(6,14)}$.

Caregiver burden is a significant problem of the caregiving experience ${ }^{(6)}$. This include the emotional costs reflected in overload and feelings of embarrassment, disruptions in caregivers' daily routine, as well as financial, health and role strain consequences $^{(2,8,15)}$.

Caregiver burden is associated with several factors including: the relationship to the care recipient, gender, age, ethnicity and care recipient behavioral problems. It is likely then that no single supportive intervention "fits all" caregivers. A variety of interventions have been developed which include: training and education programs, information-technology based support including specialized computer and telephone networks, and formal approaches to planning care ${ }^{(3)}$.

Risks related to caregiver stress could be reduced by providing information about the anticipated reactions of both the Alzheimer's patient and family members as the disease progresses. Results from community based surveys had suggested the presence of a massive demand for increased education for caregivers about Alzheimer's disease symptoms, various community services and referral agencies, and appropriate services for assessment or intervention $^{(3)}$. It is important to provide the caregiver with information which is vital for the caregiver in order for him/her to be able to understand the behavior of a person with Alzheimer's disease ${ }^{(16)}$.

Attitude is defined as a disposition to respond with some degree of favorableness or un-favorableness towards a person with AD. Attitudes shape an individuals' ability 
to understand, organize, and clarify the world around them. In fact, there is a direct correlation between lack of knowledge regarding older adults and increased negative attitudes towards the population. Education might be the first step to change attitudes. A well-designed curriculum augmented by clinical experiences with older adults is essential to promoting positive attitudes towards people with $\mathrm{AD}^{(11)}$.

There is a scarcity of data on formal caregivers' attitude and knowledge about Alzheimer's disease. So, the aim of this study is to evaluate the effect of an inservice training program about Alzheimer's disease on knowledge and attitude of formal caregivers in Damanhour City.

\section{Significance of the Study:}

There are only a few reports which provide prevalence rates of dementia in developing countries in general and in Egypt in particular. The prevalence of dementia and $\mathrm{AD}$ vary substantially in different countries. But in most countries, the prevalence of dementia varies between $6 \%$ and $8 \%$ for individuals aged 65 years or more ${ }^{(17)}$. The incidence of the disease increases with age and doubles every 5 years beyond age 65. The causes of Alzheimer's disease and other dementias are not completely understood, but researchers believe they include a combination of genetic, environmental, and lifestyle factors $^{(18)}$. Two-third of the people with dementia are projected to be from the developing countries by 2050. In Egypt, the dementia prevalence ranged from $2.01 \%$ to $5.07 \%{ }^{(19)}$. So, nurse, formal caregivers and other health care staff have a great responsibility toward persons with Alzheimer's through providing them with adequate knowledge, practical skills, identify the patient's problems correctly, understand the nature of the disease and how to help patients and families cope with Alzheimer.

\section{Aim of the Study}

Evaluate the effect of an in-service training program about Alzheimer's disease on knowledge and attitude of formal caregivers in Damanhour City.

\section{Research Hypotheses:}

1. Caregiver's knowledge level about Alzheimer disease after attending the in-service training program is higher than that before its attendance.

2. Caregiver's attitude toward Alzheimer disease after attending the in-service training program is better than that before its attendance.

\section{Materials and Method}

\section{Materials}

Design: A quasi-experimental research design was used.

Setting: The study was conducted in the available Damanhour governmental compound of residential home in Damanhour City namely Mogamae Dar El Mossenin. The compound is composed of three floors, each one considered as a separate residential home (Dar El-Hanan, Dar El-Hana and Dar El-Amal). These are the only governmental residential homes available in El-Beheira Governorate.

Subjects: The subjects comprised all available formal caregivers in the previously mentioned setting. The total number of formal caregivers in these homes amounted to 45 persons.

Tools: Two tools were used to collect the required data:

Tool I: Caregivers' socio- demographic and knowledge assessment structured interview schedule

It includes 2 parts:

Part I: Socio- demographic characteristic data such as: sex, age, Academic qualification, job, experience in years and 
attended training program or workshop related to Alzheimer.

Part II: Assesses formal caregivers' knowledge as: definition of Alzheimer, causes, risk factor, assessment and diagnosis, sign \& symptom, change in behavior and life impact, caregiving, and treatment and management.

\section{Scoring system:}

Scoring system for assessing caregivers' knowledge regarding Alzheimer Disease; this section consists of 15 items and the correct answers were pre-determined according to the literature. A score of (2) was given to the correct complete answer, a score of (1) for incomplete answer and a score of (0) for the wrong or missed answers. The total knowledge score was obtained for each caregiver (0-30). Percent of the total knowledge score was calculated as follows; they were evaluated as follows:

1 Good level $\geq 22.5$ ( $\geq 75 \%)$.

2 Satisfactory knowledge $15-<22.5 \quad$ (50$<75 \%$ ).

3 Poor knowledge $<15(<50 \%)$.

Tool II: Caregiver's attitude regarding Alzheimer $^{(9)}$

This tool is designed by El-kattan, it included the following: I feel confident about people with Alzheimer disease, I am dealing easy with Alzheimer disease, I feel uncomfortable being around Alzheimer diseased people, I am aware with Alzheimer diseased people, I would avoid an agitated person with Alzheimer disease, I feel relaxed around people with Alzheimer disease, I feel frustrated because I do not know how to help people with Alzheimer disease, It is rewarding to work with people who have Alzheimer disease, I can imagine caring for someone with Alzheimer disease and I am afraid from people with Alzheimer disease.

\section{Scoring system:}

Scoring system for assessing the caregivers' attitude regarding Alzheimer;
This section consists of 20 items. A score of (2) was given for strongly agree, a score of

(1) was given for don't agree and a score of

(0) was given for not sure.

The maximum score was ranged from (040). Percent of total attitude score was categorized as follows;

1 Negative attitude $(0-<13.32)(<33.3 \%)$. 2 Neutral attitude $(13.32-<26.68)(33.3 \%$ $<66.7 \%)$.

3 Positive attitude (26.68-40) ( $\geq 66.7 \%)$.

\section{Method}

- Before the conduction of the study, official letters from the Faculty of Nursing, Damanhour University were forwarded to the director of the residential homes to obtain their approval and assistance in order to carry out the study and interview the caregivers.

- The director of the residential homes was informed about the aim of the study and time of data collection.

- The study tools were tested for content validity by three jury experts in Community Health Nursing at Damanhour University.

- To assess reliability, the study tool, it was tested by the pilot subjects at first session and retested after 2 weeks as test-retest reliability for calculating Cronbach's Alpha which was 0.946.

- A pilot study was carried out on $10 \%$ of the formal caregivers (5 caregivers) from the only available private residential home at Damanhour City "Dar El-Saada" who were later excluded from the main study sample. They were chosen randomly to test clarity of the tools and in order to determine the approximate time needed for each interview.

- Each caregiver was interviewed individually to collect the necessary data. It took approximately 45-60 minutes to complete the study tools 
depending upon understanding and response.

- In-service training program was developed, it included 3 phases:

\section{Preparatory phase:}

$\circ$ Preparation and organization of Alzheimer's in-service training program's sessions:

- The preliminary stage was done by utilizing the assessment tools after being revised and tested for general information about Alzheimer disease. Time needed for interview ranged from 45-60 minutes. This phase lasted for 2 weeks.

- Then, Alzheimer's in-service training program's sessions were prepared by the researcher for the formal caregivers. The content of the sessions was based on review of literature, results of assessment as well as characteristics of caregivers and their needs.

\section{The aims of the sessions are to:}

- Help caregivers to get knowledge about Alzheimer Disease to prevent further complication and disease progresses.

- Improve caregivers' attitude about Alzheimer Disease.

$\circ$ Alzheimer's in-service training program' strategies:

A. Alzheimer's in-service training program methods:

Different methods of instructions were adopted as brain storming, group discussion, case study and role play.

\section{B- Teaching aids:}

Different aids were used to facilitate and illustrate teaching such as posters, handouts, and videos.

\section{Program implementation phase:}

Data were collected during period starting from the first of January 2017 to the end of May 2017. Each group of formal caregivers attended 3 sessions. The duration of each session was one hour according to presented items. Firstly, discussion of the session objectives and content were dedicated. Then, time was available for caregiver's participation and interaction. Each session was followed by a summary of knowledge presented about Alzheimer disease for about 15 minutes. Different methods of instructions and teaching aids mentioned before were used.

\section{Session (1):}

- Overview of AD and prevalence

- Common causes of AD

- Incidence and lifetime risk of AD

Session (2):

- Identify symptoms of AD

- Diagnosis of AD

- Disease progresses and mortality

\section{Session (3):}

- Social, cognitive engagement and changed behavior

- Education and Caregiving

- Treatment of AD and interventions

- Pharmacological treatment

- Nonpharmacological therapy

\section{Evaluation phase:}

Evaluation of the training program was done immediately and then three month after its implementation by comparing the change in formal caregiver level of knowledge and attitudes through applying the same tool of pre-test as post-test. 


\section{Ethical considerations:}

Verbal consent was obtained from the caregivers after explanation of the aim of the study. Privacy was maintained during process of data collection. Confidentiality and anonymity of caregivers' response were guaranteed.

\section{Statistical Analysis}

After data were collected, they were coded and analyzed. The statistical package for social sciences (SPSS/version 20) software was utilized for data analysis and tabulation. Statistically significant at $\mathrm{p} \leq 0.05$.

\section{The following statistical measures were} used:

\section{Descriptive statistics:}

- Count and percentage: used for describing and summarizing qualitative data.

- Arithmetic mean (X), standard deviation (SD). They were used as measures of control tendency and dispersion respectively for normally distributed quantitative data.

\section{Analytical statistics:}

Chi square (X2): it was used to test the association between categories of qualitative variables.

\section{Results}

Table (1) shows the socio-demographics characteristic of the studied subjects. Males were $(26.7 \%)$ and females $(73.3 \%)$. The age of the caregivers ranged from 24 - 54 years, with a mean age was $27.25 \pm 0.76$ years.

Concerning their level of education, most $(46.7 \%)$ of caregivers have primary education or illiterate, majority $(88.9 \%)$ of them were married. Those from urban residence $(68.9 \%)$ were higher than rural $(31.1 \%)$.

Regarding to caregivers' experience, more than half $(51.1 \%)$ of them have $5-<10$ years of experience in caring of elders, the mean years were $9.25 \pm 0.76$ years. The majority (93.3\%) had no family history of Alzheimer. Only $17.8 \%$ reported caring for person with $\mathrm{AD}$ and $13.3 \%$ attended an educational program about Alzheimer's disease.

Table (2) shows that only $3(6.7 \%)$ of the caregivers had good knowledge before program implementation this percent increased to $40.0 \%$ immediately after the implementation of in-service training program compared to one third after three months of implementation. Moreover, nearly three quarters of caregivers before program implementation had poor knowledge compared to more than one third three months later on. The difference was statistically significant $(\mathrm{P}=0.0021)$. The same was observed with their attitude where $6.7 \%$ showed positive attitude toward Alzheimer disease prior to in-service training program compared to $(46.7 \%)$ immediately after the implementation of inservice training program. Then this percent was descend to $40 \%$ after three months of program implementation. The difference was statistically significant $(\mathrm{P}=0.003)$.

Table (3) shows the relation between caregiver's knowledge and attitude 3 months post in-service training program. It was found that nearly half of caregivers $(40.0 \%)$ who have positive attitude also have good and satisfactory level of knowledge regarding Alzheimer disease at post implementation of in-service training program.

Moreover, those have neutral attitude regarding Alzheimer disease at post program were $46.7 \%$ and the majority $(84.6 \%)$ of them have satisfactory level of knowledge followed by $62.5 \%$ with poor knowledge. There was statistical significant relation between caregiver's knowledge level and attitude regarding Alzheimer disease at 3 months post in-service training program implementation $(\mathrm{P}=0.0001)$.

Figure (1) illustrates caregivers' sources of knowledge regarding Alzheimer disease. It was found that more than half $(51.1 \%)$ of 
caregivers acquired their knowledge from mass-media as T.V., internet and magazines, newspaper followed by friends/ peer group were $46.7 \%$, doctors $15.6 \%$ and workshops/training program $13.3 \%$.

Table (4) shows the relation between caregiver's knowledge 3 months after the implementation of in-service training program and their socio-demographic data. A statistical significant relation regarding to age $(\mathrm{P}=0.042)$, level of education $(\mathrm{P}=0.039)$ was observed while no statistical significant relation regarding gender, marital status, place of residence, years of experience, having family members with Alzheimer's disease, caring for someone with Alzheimer's disease, attending an educational program.

Table (5) shows the relation between caregiver's attitude 3 months after the implementation of in-service training program and their socio-demographic profile. A statistical significant relation regarding to age $(\mathrm{P}=0.043)$, level of education $(\mathrm{P}=0.039)$, years of experience $(\mathrm{P}=0.021)$ was observed while no statistical significant relation regarding gender, marital status, place of residence.

\section{Discussion}

Alzheimer's disease (AD) is a chronic, progressive neurodegenerative disorder in the elderly. It creates cognitive and functional instabilities that lead to ongoing and persistent loss of autonomy as well as sever behavioral problems which needs increasing levels of care. Family caregivers can provide sufficient care in the initial stages of the disease, but residence homes and psychiatric hospital care often become necessary when the home carers are no longer able to cope ${ }^{(20)}$. This disease creates a substantial burden on human and financial resources $^{(21)}$.

Regarding the presence of association between caregivers' socio-demographic characteristics and their knowledge, and attitude levels related to Alzheimer disease. The present study spotted statistical significant associations between age, level of education and knowledge of formal caregivers and that may be due to the age group of them was 24-54 years which reflect on their behavior and have the ability to learn more than others. Also this study showed statistical significant relationships between age, level of education, experience and attitude of caregivers, this may be due to presence of reasonable number of the caregivers have secondary education and higher degree level. These were in the same line with Scerri A. ${ }^{(22)}$, who stated that older age and clinical experience are associated significantly with a more positive attitude and that age, academic year, training and previous care of dementia patients during their clinical placement were all found to be associated with increased knowledge and positive attitudes. This was congruent with Faronb J. ${ }^{(23)}$, who informed that there was a statistically significant association between attitude and perception and age category.

Regarding levels and mean scores of total formal caregivers' knowledge and attitude at pre and post in-service training program about Alzheimer disease, the present study results showed that most of caregivers had poor level of knowledge associated with neutral level of attitude regarding Alzheimer disease at pre-program. This may be due to diversity in their educational background in addition to that the majority of them did not receive any training programs on care for Alzheimer's patients. This result is in agreement with Smyth W. ${ }^{(24)}$, who stated that defect in knowledge about dementia were identified among Australian health care staff. These were disagree with Mellor P. ${ }^{(25)}$ who reported that, nurses have positive attitudes toward elderly people, and they have significant deficits knowledge in clinical practice. However, there was statistical significant improvement among caregivers' knowledge and attitude level 3 months after the implementation of training program compared with pre-program, this improvement may be due to the effect of the program on the caregivers which denotes the 
significant and effectiveness of the program. This result is consistent with Villars $\mathrm{H}^{(26)}$, who reported a significant positive effect of a therapeutic educational program on patients' life and that of their caregivers. Additionally, Palmer J. ${ }^{(27)}$, informed that, significant improvement on the posttest participants' attitudes, practices, and confidence. This study results were incompatible with Jeon Y. ${ }^{(28)}$, who stated that training for residential care staff did not improve staff attitudes.

Regarding the presence of association between caregivers' knowledge, and attitude levels regarding Alzheimer disease 3 months post implementation of the program. The present study identified statistically significant relationships between caregivers' knowledge, and attitude levels post program. Similarly to Sensel A. ${ }^{(29)}$, who reported that participants who had higher knowledge scores also had more positive attitude scores.

\section{Conclusion}

Based on findings of the present study, it could be concluded that results of this study confirmed the hypothesis as caregiver's knowledge level about Alzheimer disease after attending the in-service training program is higher than that before its attendance. Furthermore, caregiver's attitude toward Alzheimer disease after attending the in-service training program is better than that before its attendance.

It was clearly that implementation of inservice training program had a positive effect on formal caregivers' knowledge and attitude about Alzheimer's disease.

\section{Recommendations}

The following recommendations can be made in the light of the current study results:

- Caregivers for elders should be knowledgeable and updated by attending in-service training program, and workshops regarding Alzheimer disease.

- Expand the role of social media for increasing community awareness about caring for patient with Alzheimer.

- Future studies are needed to determine the most effective learning method for caregivers to improve their knowledge and attitudes regarding Alzheimer disease. 
Table (1): Distribution of caregivers according to their socio-demographic characteristics

\begin{tabular}{|c|c|c|}
\hline \multirow{2}{*}{ Socio-demographic characteristics } & \multicolumn{2}{|c|}{ Caregivers $(n=45)$} \\
\hline & No. & $\%$ \\
\hline $\begin{array}{c}\text { Gender } \\
\qquad \quad \text { Male } \\
\text { - Female }\end{array}$ & $\begin{array}{l}12 \\
33\end{array}$ & $\begin{array}{l}26.7 \\
73.3\end{array}$ \\
\hline $\begin{aligned} & \text { Age } \\
&- \leq 30 \\
& \bullet 31- \\
& \bullet 41- \\
& \cdot 51+ \\
&\end{aligned}$ & $\begin{array}{c}29 \\
4 \\
9 \\
3\end{array}$ & $\begin{array}{c}64.4 \\
8.9 \\
20.0 \\
6.7\end{array}$ \\
\hline Mean \pm SD & \multicolumn{2}{|c|}{$27.25 \pm 0.76$} \\
\hline $\begin{array}{l}\text { Level of education } \\
\text { - Illiterate } \\
\text { - Primary education } \\
\text { - Preparatory education } \\
\text { - Secondary education } \\
\text { - Bachelor }\end{array}$ & $\begin{array}{c}8 \\
13 \\
4 \\
12 \\
8 \\
\end{array}$ & $\begin{array}{r}17.8 \\
28.9 \\
8.9 \\
26.7 \\
17.8\end{array}$ \\
\hline $\begin{array}{cl}\text { Marital status: } \\
\text { - } \quad \text { Married } \\
\text { - } \quad \text { Unmarried } \\
\end{array}$ & $\begin{array}{c}40 \\
5\end{array}$ & $\begin{array}{l}88.9 \\
11.1\end{array}$ \\
\hline $\begin{array}{c}\text { Place of residence } \\
\text { - Urban } \\
\text { - } \quad \text { Rural } \\
\end{array}$ & $\begin{array}{l}31 \\
14\end{array}$ & $\begin{array}{l}68.9 \\
31.1 \\
\end{array}$ \\
\hline $\begin{array}{l}\text { Experience (years): } \\
\qquad \quad<5 \text { years } \\
\text { - } 5-<10 \text { years } \\
\text { - } 10+ \\
\end{array}$ & $\begin{array}{c}5 \\
23 \\
17 \\
\end{array}$ & $\begin{array}{l}11.1 \\
51.1 \\
37.8\end{array}$ \\
\hline Mean \pm SD & \multicolumn{2}{|c|}{$9.25 \pm 0.76$} \\
\hline $\begin{array}{l}\text { Family history of Alzheimer's disease: } \\
\text { - Yes } \\
\text { - No }\end{array}$ & $\begin{array}{c}3 \\
42\end{array}$ & $\begin{array}{c}6.7 \\
93.3 \\
\end{array}$ \\
\hline $\begin{array}{l}\text { Caring for an Alzheimer person: } \\
\text { - Yes } \\
\text { - No }\end{array}$ & $\begin{array}{c}8 \\
37\end{array}$ & $\begin{array}{l}17.8 \\
82.2\end{array}$ \\
\hline $\begin{array}{l}\text { Attendance of educational program abc } \\
\text { - Yes } \\
-\quad \text { No } \\
\end{array}$ & $\begin{array}{c}6 \\
39 \\
\end{array}$ & $\begin{array}{l}13.3 \\
86.7 \\
\end{array}$ \\
\hline
\end{tabular}


Table (2): Distribution of caregivers according to their level of knowledge and attitude pre and post in-service training program

\begin{tabular}{|c|c|c|c|c|c|c|c|}
\hline \multirow[t]{2}{*}{ Items } & \multicolumn{2}{|c|}{$\begin{array}{c}\text { Pre } \\
\text { in-service program } \\
(n=45)\end{array}$} & \multicolumn{2}{|c|}{$\begin{array}{c}\text { Immediately Post } \\
\text { in-service program } \\
(n=45)\end{array}$} & \multicolumn{2}{|c|}{$\begin{array}{c}3 \text { months Post } \\
\text { in-service program } \\
(n=45)\end{array}$} & \multirow[t]{2}{*}{$\begin{array}{c}\mathbf{X}^{2} \\
\mathbf{p}\end{array}$} \\
\hline & No. & $\%$ & No. & $\%$ & No. & $\%$ & \\
\hline \multicolumn{8}{|l|}{ Knowledge } \\
\hline Good $(\geq 75 \%)$ & 3 & 6.7 & 18 & 40.0 & 16 & 35.6 & \multirow{3}{*}{$\begin{array}{c}18.22 \\
0.0021 *\end{array}$} \\
\hline $\begin{array}{l}\text { Satisfactory (50- } \\
<75 \%)\end{array}$ & 9 & 20.0 & 12 & 26.7 & 13 & 28.9 & \\
\hline Poor $(<50 \%)$ & 33 & 73.3 & 15 & 33.3 & 16 & 35.6 & \\
\hline \multicolumn{8}{|c|}{ The mean score of knowledge } \\
\hline Mean \pm SD & \multicolumn{2}{|c|}{$11.2 \pm 4.8$} & \multirow{2}{*}{\multicolumn{2}{|c|}{$18.3 \pm 5.4$}} & \multicolumn{2}{|c|}{$17.62 \pm 4.78$} & \\
\hline \multicolumn{6}{|l|}{ Attitude } & & \\
\hline Positive $(\geq 66.7 \%)$ & 3 & 6.7 & 21 & 46.7 & 18 & 40.0 & \multirow{3}{*}{$\begin{array}{c}16.72 \\
0.003^{*}\end{array}$} \\
\hline $\begin{array}{l}\text { Neutral }(33.3 \%- \\
<66.7 \%)\end{array}$ & 35 & 77.8 & 20 & 44.4 & 21 & 46.7 & \\
\hline Negative $(<33.3 \%)$ & 7 & 15.6 & 4 & 8.9 & 6 & 13.3 & \\
\hline \multicolumn{8}{|c|}{ The mean score of attitude } \\
\hline Mean \pm SD & \multicolumn{2}{|c|}{$9.1 \pm 2.7$} & \multicolumn{2}{|c|}{$12.5 \pm 4.0$} & \multicolumn{2}{|c|}{$11.9 \pm 3.98$} & \\
\hline
\end{tabular}

*: Statistically significant at $\mathrm{p} \leq 0.05$

Table (3): Relation between knowledge and attitude of the caregivers 3 months post implementation of in-service training program

\begin{tabular}{|c|c|c|c|c|c|c|}
\hline \multirow{2}{*}{\multicolumn{3}{|c|}{ Items }} & \multicolumn{3}{|c|}{$\begin{array}{c}\text { knowledge of caregivers } 3 \text { months post } \\
\text { implementation of in-service training } \\
\text { program }\end{array}$} & \multirow[t]{2}{*}{$\begin{array}{c}\text { Total } \\
(n=45)\end{array}$} \\
\hline & & & Good & Satisfactory & Poor & \\
\hline \multirow{6}{*}{$\begin{array}{l}\text { Attitude of caregivers } 3 \\
\text { months post } \\
\text { implementation of in- } \\
\text { service training program }\end{array}$} & \multirow{2}{*}{ Positive } & No & 16 & 2 & 0 & 18 \\
\hline & & $\%$ & $100.0 \%$ & $15.4 \%$ & $0.0 \%$ & $40.0 \%$ \\
\hline & \multirow{2}{*}{ Neutral } & No & 0 & 11 & 10 & 21 \\
\hline & & $\%$ & $0.0 \%$ & $84.6 \%$ & $62.5 \%$ & $46.7 \%$ \\
\hline & \multirow{2}{*}{ Negative } & No & 0 & 0 & 6 & 6 \\
\hline & & $\%$ & $0.0 \%$ & $0.0 \%$ & $37.5 \%$ & $13.3 \%$ \\
\hline \multirow{2}{*}{\multicolumn{2}{|c|}{ Total }} & No & 16 & 13 & 16 & 45 \\
\hline & & $\%$ & $100.0 \%$ & $100.0 \%$ & $100.0 \%$ & $100.0 \%$ \\
\hline & & \multicolumn{3}{|c|}{$\begin{array}{c}45.9 \\
0.0001 *\end{array}$} & \\
\hline
\end{tabular}

*: Statistically significant at $\mathrm{p} \leq 0.05$

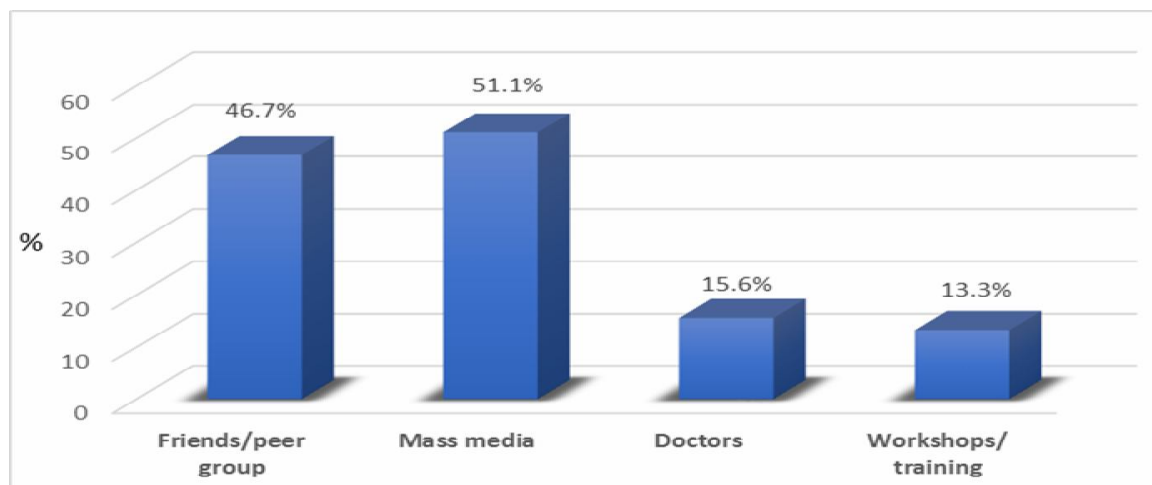

Figure (1): Sources of caregivers' knowledge regarding Alzheimer disease 
Table (4): Relation between socio-demographic profile and knowledge of caregivers 3 months post implementation of in-service training program

\begin{tabular}{|c|c|c|c|c|c|c|c|}
\hline \multirow{3}{*}{ Socio-demographic data } & \multicolumn{6}{|c|}{$\begin{array}{c}\text { knowledge of caregivers } 3 \text { months post } \\
\text { implementation of in-service training program }\end{array}$} & \multirow{3}{*}{$\begin{array}{c}\mathbf{X}^{2} \\
\mathbf{p}\end{array}$} \\
\hline & \multicolumn{2}{|c|}{$\begin{array}{l}\text { Good } \\
\text { "n=16" }\end{array}$} & \multicolumn{2}{|c|}{$\begin{array}{l}\text { Satisfactory } \\
\text { "n=13" }\end{array}$} & \multicolumn{2}{|c|}{$\begin{array}{c}\text { Poor } \\
\text { “n=16" }\end{array}$} & \\
\hline & No. & $\%$ & No. & $\%$ & No. & $\%$ & \\
\hline $\begin{aligned} \text { Gender } & \\
\bullet & \text { Male } \\
- & \text { Female }\end{aligned}$ & $\begin{array}{c}2 \\
14\end{array}$ & $\begin{array}{l}16.7 \\
42.4\end{array}$ & $\begin{array}{c}3 \\
10\end{array}$ & $\begin{array}{l}25.0 \\
30.3\end{array}$ & $\begin{array}{l}7 \\
9\end{array}$ & $\begin{array}{l}58.3 \\
27.3\end{array}$ & $\begin{array}{c}4.11 \\
0.147\end{array}$ \\
\hline $\begin{aligned} & \text { Age } \\
&- \leq 30 \\
&- 31- \\
&- 41- \\
&- 51+ \\
&\end{aligned}$ & $\begin{array}{l}11 \\
2 \\
3 \\
0\end{array}$ & $\begin{array}{c}37.9 \\
50.0 \\
33.3 \\
0.0 \\
\end{array}$ & $\begin{array}{l}8 \\
0 \\
2 \\
0\end{array}$ & $\begin{array}{c}27.6 \\
0.0 \\
22.2 \\
0.0 \\
\end{array}$ & $\begin{array}{l}10 \\
2 \\
4 \\
3\end{array}$ & $\begin{array}{c}34.5 \\
50.0 \\
44.4 \\
100.0\end{array}$ & $\begin{array}{c}7.21 \\
0.042^{*}\end{array}$ \\
\hline $\begin{array}{l}\text { Level of education } \\
\text { - Uneducated (illiterate) } \\
\text { - Primary education } \\
\text { - Preparatory education } \\
\text { - Secondary education } \\
\text { - } \text { Bachelor }\end{array}$ & $\begin{array}{l}0 \\
3 \\
1 \\
5 \\
7\end{array}$ & $\begin{array}{c}0.0 \\
23.1 \\
25.0 \\
41.7 \\
87.5\end{array}$ & $\begin{array}{l}2 \\
3 \\
2 \\
5 \\
1\end{array}$ & $\begin{array}{l}25.0 \\
23.1 \\
50.0 \\
41.7 \\
12.5\end{array}$ & $\begin{array}{l}6 \\
7 \\
1 \\
2 \\
0\end{array}$ & $\begin{array}{c}75.0 \\
53.8 \\
25.0 \\
16.7 \\
0.0\end{array}$ & $\begin{array}{c}8.11 \\
0.039 *\end{array}$ \\
\hline $\begin{array}{cl}\text { Marital status: } \\
\bullet \quad \text { Married } \\
\bullet \quad \text { Unmarried } \\
\end{array}$ & $\begin{array}{c}14 \\
2\end{array}$ & $\begin{array}{l}35.0 \\
40.0\end{array}$ & $\begin{array}{c}11 \\
2\end{array}$ & $\begin{array}{l}27.5 \\
40.0\end{array}$ & $\begin{array}{c}15 \\
1\end{array}$ & $\begin{array}{l}37.5 \\
20.0\end{array}$ & $\begin{array}{c}1.26 \\
0.394\end{array}$ \\
\hline $\begin{array}{cc}\text { Place of residence } \\
\text { - } \quad \text { Urban } \\
\text { - } & \text { Rural } \\
\end{array}$ & $\begin{array}{c}11 \\
5\end{array}$ & $\begin{array}{l}35.5 \\
35.7\end{array}$ & $\begin{array}{l}7 \\
6\end{array}$ & $\begin{array}{l}22.6 \\
42.9\end{array}$ & $\begin{array}{c}13 \\
3\end{array}$ & $\begin{array}{l}41.9 \\
21.4\end{array}$ & $\begin{array}{c}3.66 \\
0.127\end{array}$ \\
\hline $\begin{array}{l}\text { Experience (years): } \\
\text { - } \quad<5 \text { years } \\
\text { - } \quad 5-<10 \text { years } \\
\text { - } \geq 10\end{array}$ & $\begin{array}{c}3 \\
10 \\
3\end{array}$ & $\begin{array}{l}60.0 \\
43.5 \\
17.6\end{array}$ & $\begin{array}{c}2 \\
10 \\
4\end{array}$ & $\begin{array}{l}40.0 \\
43.5 \\
23.5\end{array}$ & $\begin{array}{c}0 \\
3 \\
10\end{array}$ & $\begin{array}{c}0.0 \\
13.0 \\
58.8\end{array}$ & $\begin{array}{c}2.95 \\
0.225\end{array}$ \\
\hline $\begin{array}{l}\text { Family history of Alzheimer's } \\
\text { disease: } \\
\text { - Yes } \\
\text { - No } \\
\end{array}$ & $\begin{array}{c}1 \\
15\end{array}$ & $\begin{array}{l}33.3 \\
35.7\end{array}$ & $\begin{array}{c}1 \\
12\end{array}$ & $\begin{array}{l}33.3 \\
28.6\end{array}$ & $\begin{array}{c}1 \\
15\end{array}$ & $\begin{array}{l}33.3 \\
35.7\end{array}$ & $\begin{array}{l}1.693 \\
0.412\end{array}$ \\
\hline $\begin{array}{l}\text { Caring for an Alzheimer } \\
\text { person: } \\
\text { - Yes } \\
-\quad \text { No }\end{array}$ & $\begin{array}{c}4 \\
12\end{array}$ & $\begin{array}{l}50.0 \\
32.4\end{array}$ & $\begin{array}{c}2 \\
11\end{array}$ & $\begin{array}{l}25.0 \\
29.7\end{array}$ & $\begin{array}{c}2 \\
14\end{array}$ & $\begin{array}{l}25.0 \\
37.8\end{array}$ & $\begin{array}{c}5.06 \\
0.082\end{array}$ \\
\hline $\begin{array}{l}\text { Attendance of educational pro } \\
\text { - Yes } \\
\text { - No }\end{array}$ & $\begin{array}{c}\mathbf{m} \text { abc } \\
2 \\
14\end{array}$ & $\begin{array}{c}\text { Alzhe } \\
33.3 \\
35.9\end{array}$ & $\begin{array}{c}\text { or d } \\
1 \\
12\end{array}$ & $\begin{array}{r}\text { entia: } \\
16.7 \\
30.8\end{array}$ & $\begin{array}{c}3 \\
13\end{array}$ & $\begin{array}{l}50.0 \\
33.3\end{array}$ & $\begin{array}{c}2.1 \\
0.311\end{array}$ \\
\hline
\end{tabular}

*: Statistically significant at $\mathrm{p} \leq 0.05$ 
Table (5): Relation between socio-demographic profile and attitude of caregivers 3 months post implementation of in-service training program

\begin{tabular}{|c|c|c|c|c|c|c|c|}
\hline \multirow{3}{*}{ Socio-demographic data } & \multicolumn{6}{|c|}{$\begin{array}{c}\text { Attitude of caregivers post implementation of in-service } \\
\text { training program }\end{array}$} & \multirow{3}{*}{$\begin{array}{c}X^{2} \\
\mathbf{p}\end{array}$} \\
\hline & \multicolumn{2}{|c|}{$\begin{array}{l}\text { Positive } \\
\text { "n=21" }\end{array}$} & \multicolumn{2}{|c|}{$\begin{array}{l}\text { Neutral } \\
\text { "n=20" }\end{array}$} & \multicolumn{2}{|c|}{$\begin{array}{c}\text { Negative } \\
\text { "n=4" }\end{array}$} & \\
\hline & No. & $\%$ & No. & $\%$ & No. & $\%$ & \\
\hline \begin{aligned} \multicolumn{2}{l}{ Gender } \\
\[ \quad \text { Male } \] \\
- $\quad$ Female \\
\end{aligned} & $\begin{array}{c}3 \\
18\end{array}$ & $\begin{array}{l}25.0 \\
54.5\end{array}$ & $\begin{array}{c}7 \\
13\end{array}$ & $\begin{array}{l}58.3 \\
39.4\end{array}$ & $\begin{array}{l}2 \\
2\end{array}$ & $\begin{array}{c}16.7 \\
6.1\end{array}$ & $\begin{array}{l}2.470 \\
0.176\end{array}$ \\
\hline $\begin{aligned} \text { Age } & \\
- & \leq 30 \\
- & 31- \\
- & 41- \\
\text { - } & 51+\end{aligned}$ & $\begin{array}{c}14 \\
2 \\
4 \\
1\end{array}$ & $\begin{array}{l}48.3 \\
50.0 \\
44.4 \\
33.3 \\
\end{array}$ & $\begin{array}{c}13 \\
1 \\
5 \\
1\end{array}$ & $\begin{array}{l}44.8 \\
25.0 \\
55.6 \\
33.3\end{array}$ & $\begin{array}{l}2 \\
1 \\
0 \\
1\end{array}$ & $\begin{array}{c}6.9 \\
25.0 \\
0.0 \\
33.3\end{array}$ & $\begin{array}{r}7.402 \\
0.049^{*}\end{array}$ \\
\hline $\begin{array}{cl}\text { Level of education } \\
\text { - } & \text { Uneducated } \\
& \text { (illiterate) } \\
\text { - } & \text { Primary } \\
\text { - } & \text { Preparatory } \\
\text { - } & \text { Secondary } \\
\text { - } & \text { Bachelor } \\
\end{array}$ & $\begin{array}{l}4 \\
4 \\
3 \\
6 \\
4\end{array}$ & $\begin{array}{l}50.0 \\
30.8 \\
75.0 \\
50.0 \\
50.0 \\
\end{array}$ & $\begin{array}{l}4 \\
8 \\
1 \\
5 \\
2\end{array}$ & $\begin{array}{l}50.0 \\
61.5 \\
25.0 \\
37.5 \\
25.0\end{array}$ & $\begin{array}{l}0 \\
1 \\
0 \\
1 \\
2\end{array}$ & $\begin{array}{c}0.0 \\
7.7 \\
0.0 \\
12.5 \\
25.0\end{array}$ & $\begin{array}{c}6.531 \\
0.038^{*}\end{array}$ \\
\hline $\begin{array}{cl}\text { Marital status: } \\
\bullet \quad \text { Married } \\
\bullet \quad \text { Unmarried } \\
\end{array}$ & $\begin{array}{c}20 \\
1\end{array}$ & $\begin{array}{l}50.0 \\
20.0\end{array}$ & $\begin{array}{c}17 \\
3\end{array}$ & $\begin{array}{l}42.5 \\
60.0 \\
\end{array}$ & $\begin{array}{l}3 \\
1\end{array}$ & $\begin{array}{c}7.5 \\
20.0\end{array}$ & $\begin{array}{l}1.945 \\
0.378\end{array}$ \\
\hline $\begin{array}{c}\text { Place of residence } \\
\text { - } \quad \text { Urban } \\
\text { - } \quad \text { Rural } \\
\end{array}$ & $\begin{array}{c}12 \\
9\end{array}$ & $\begin{array}{l}38.7 \\
64.3\end{array}$ & $\begin{array}{c}15 \\
5\end{array}$ & $\begin{array}{l}48.4 \\
35.7\end{array}$ & $\begin{array}{l}4 \\
0\end{array}$ & $\begin{array}{c}12.9 \\
0.0\end{array}$ & $\begin{array}{l}3.507 \\
0.173\end{array}$ \\
\hline $\begin{array}{c}\text { Experience (years): } \\
\text { - } \quad<5 \text { years } \\
\text { - } \quad 5-<10 \text { years } \\
\text { - } \quad \geq 10\end{array}$ & $\begin{array}{c}5 \\
11 \\
10\end{array}$ & $\begin{array}{c}100.0 \\
47.8 \\
58.8\end{array}$ & $\begin{array}{c}0 \\
12 \\
5\end{array}$ & $\begin{array}{l}0.00 \\
52.2 \\
29.4\end{array}$ & $\begin{array}{l}0 \\
0 \\
2\end{array}$ & $\begin{array}{l}0.00 \\
0.00 \\
11.8\end{array}$ & $\begin{array}{c}5.366 \\
0.025^{*}\end{array}$ \\
\hline
\end{tabular}

*:Statistically significant at $\mathrm{p} \leq 0.05$. 


\section{References}

1. Ko JW. Alzheimer's disease and related disorders caregiver's acceptance of a webbased structured written emotional expression intervention. $\mathrm{PhD}$ diss., University of Iowa, 2011. http://ir.uiowa.edu/etd/2729. Retrieved on $23 \backslash 12 \backslash 2017$.

2. Duthey B. Alzheimer Disease and other Dementias. 20 February 2013.

3. Thompson CA, Spilsbury K, Hall J, Birks Y, Barnes C \& Adamson J. Systematic review of information and support interventions for caregivers of people with dementia BMC Geriatrics 2007, 7:18.

4. Alzheimer's Association Report. Alzheimer's \& Dementia. 2013; 9: 208245.

5. Scott, Cathy B, "Alzheimer's Disease Caregiver Burden: Does Resilience Matter?" PhD diss., University of Tennessee, 2010. http://trace.tennessee.edu/utk_graddiss/912 Retrieved on 23\12\2017.

6. Wassman EM. "The Experiences of Caregivers Caring for Loved Ones with Dementia". Master thesis, St. Catherine University, 2012. http://sophia.stkate.edu/msw_papers/100. Retrieved on 23\12\2017.

7. Klein M. Dementia Caregivers: An Exploration of Their Knowledge, Beliefs, and Behavior Regarding Advance Care Planning for End-of-Life Care. PhD diss., Virginia Commonwealth University, May 2014.

8. Coetsee MJ. The psychological health implications of social support for the Alzheimer caregiver. Master thesis, University of Pretoria, March 2007.

9. El-kattan EB, EL-afandy AO, Abd El-fatah WO. Training of Formal Caregivers Dealing with Alzheimer Diseased Patients at Helwan City Cairo Egypt. American Journal of Nursing Science. 2017; Vol. 6, No. 3, pp. 146-158. doi: 10.11648/j.ajns.20170603.12.
10. Yektatalab S, Sharif F, Kaveh MH, Khoshknab MF, Petramfar P. Living with and Caring for Patients with Alzheimer's Disease in Nursing Homes. Journal of Caring Sciences. 2013; 2(3), 187-195. doi: $10.5681 /$ jcs.2013.023. http://journals.tbzmed.ac.ir/ JCS. Retrieved on 10 January 2018.

11. Kimzey M. "Nursing Students' Attitude and Knowledge of Alzheimer's Disease". PhD diss., the University of Texas at Tyler, May $2014 \quad$ http://hdl.handle.net/10950/216 Retrieved on 22\12\2017.

12. Connecting the dots: formal and informal care. Senior Government Officials Meeting- $10^{\text {th }}$ of June 2014, Hyderabad. www.IFA-FIV.org. Retrieved on $2612 \backslash 2018$.

13. Reid RA. Improving the Experiences of Informal and Formal Alzheimer's Disease and Dementias Caregivers. PhD diss., Walden University, 2015.

14. Sharma N, Chakrabarti S, Grover S. Gender differences in caregiving among family - caregivers of people with mental illnesses. World J Psychiatr. 2016 March; 22; 6(1): 7-17.

15. Sarkar S. Impact of Caregiving Role in the Quality of Life of Family Caregivers for Persons with Alzheimer's Disease. Master thesis, Minnesota State University, May, 2015.

16. Arffman R. Social Support Promoting Coping for Caregivers Caring of People with Alzheimer's disease. Bachelor's Thesis Jamk University of Applied Science, November 2012.

17. Zaitoun AM, Sarhan AA, Selim AM, Mousa GR. Epidemiological Study of Dementia after Retirement. Egypt J. Neurol. Psychiat. Neurosurg. 2008; 45(1): 65-74.

18. National Center for Chronic Disease Prevention and Health Promotion. Alzheimer's Disease: Promoting Health and Independence for an Aging Population. 2017. 
19. Elshahidi MH, Elhadidi MA, Sharaqi AA, Mostafa A, Elzhery MA. Prevalence of dementia in Egypt: a systematic review. Neuropsychiatric Disease and Treatment. 2017; 13: 715-720.

20. Rigaud AS, Fagnani F, Bayle C, Latour F, Traykov L \& Forette F. Patients With Alzheimer's Disease Living at Home in France: Costs and Consequences of the Disease. Journal of Geriatric Psychiatry and Neurology. 2003; Vol. 16, No. X.

21. Nijhof N. Ehealth for people with dementia in home-based and residential care. $\mathrm{PhD}$ diss., University of Twente, 2013.

22. Scerri A. \& Scerri C. Nursing students' knowledge and attitudes towards dementia - A questionnaire survey, A Department of Nursing, Faculty of Health Sciences, Nurse Education Today Journal, 2013. Available at: www.elsevier.com/nedt. Retrieved on $15 \backslash 1 \backslash 2018$.

23. Faronb JO, Adebowale O, Faronbia GO, Musaa OO, Ayamolowoa SJ. Perception knowledge and attitude of nursing students towards the care of older patients. International Journal of Africa Nursing Sciences. 2017; 7: 37-42.

24. Smyth W, Fielding E, Beattie E, Gardner A, Moyle W, Franklin S, Hines S \& MacAndrew M. A survey based study of knowledge of Alzheimer's disease among health care staff. BMC Geriatrics. 2013; $13: 2$.

25. Mellor P. Nurses' attitudes toward elderly people and knowledge of Geriatric care in a multi-purpose health services (MPHS) Australian Journal of Advanced Nursing. 2007; 24 (3).

26. Villars H, Charlotte D, Amélie P, Bruno V, Fati N. Impact of a therapeutic educational program on quality of life in Alzheimer's disease: Results of a pilot study. JAlzheimers Dis. 2015; 43 (1):167-76.

27. Palmer JL, Lach HW, McGillick J, Murphy-White M, Carroll MB. \& Johanna L. Armstrong JL. The Dementia Friendly Hospital Initiative education program for acute care nurses and staff. J ContinEducNurs. Sep. 2014; 45 (9):416-24.
28. Jeon Y. et al. Staff outcomes from the caring for aged dementia care resident study (CADRES): A cluster randomized trial. International Journal of Nursing Studies. 2011; 49 (5): 508-518.

29. Sensel AJ. Assessment of occupational therapists' attitudes and knowledge of Alzheimer's disease. Digital Repository. Master's and Doctoral Projects. The University of Toledo, 2008. Available at http://utdr.utoledo.edu/graduate-projects. Retrieved on $25 \backslash 1 \backslash 2018$. 